\title{
PSS business model conceptualization and application
}

Federico Adrodegari, Nicola Saccani, Christian Kowalkowski and J yrki Vilo

The self-archived postprint version of this journal article is available at Linköping University Institutional Repository (DiVA):

http:/ / urn.kb.se/ resolve?urn=urn:nbn:se:liu:diva-140977

N.B.: When citing this work, cite the original publication.

This is an electronic version of an article published in:

Adrodegari, F., Saccani, N., Kowalkowski, C., Vilo, J ., (2017), PSS business model conceptualization and application, Production planning \& control (Print), 28(15), 1251-1263.

https:// doi.org/ 10.1080/ 09537287.2017.1363924

Original publication available at:

https:/ / doi.org/ 10.1080/09537287.2017.1363924

Copyright: Taylor \& Francis (STM, Behavioural Science and Public Health Titles)

http:// www.tandf.co.uk/journals/ default.asp 


\title{
PSS business model conceptualization and application
}

\author{
Federico Adrodegari ${ }^{*}$, Nicola Saccani ${ }^{1}$, Christian Kowalkowski ${ }^{2,3}$, Jyrki \\ Vilo ${ }^{4}$ \\ ${ }^{1}$ University of Brescia - Department of Mechanical and Industrial Engineering, 25032 \\ Brescia, Italy; ${ }^{2}$ Linköping University - Department of Management and Engineering, \\ 58183 Linköping, Sweden; ${ }^{3}$ Hanken School of Economics - Department of Marketing, \\ 00101 Helsinki, Finland; ${ }^{4}$ KINE Robot Solutions, 20100 Turku, Finland.
}

*Corresponding author: federico.adrodegari@unibs.it

Abstract:

The discussion about business models has gained considerable attention in the last decade. Business model frameworks have been developed in literature as management methods helping companies to comprehend and analyse their current business logic and guide the deployment of new strategies. In response to calls for a deeper understanding of the application of a business model approach to product-service systems (PSS), this study develops a two-level hierarchical framework that: (i) includes a set of components with pertinent, second-order variables to take into account when undergoing the shift from products to solutions; (ii) supports industrial companies, especially SMEs, in designing their future business model and in consistently planning the actions needed to implement it. The framework was applied and refined within real-life settings. The application to KINE - a robot solutions supplier - shows how key challenges faced by servitizing firms may be thoroughly addressed through the adoption of a business model perspective

Keywords: product-service systems (PSS); servitization; business model (BM); framework; SMEs

This is a so-called personal version (author's manuscript as accepted for publishing after the review process but prior to final layout and copy editing) of the article. Readers are kindly asked to use the official publication in references.

To cite this article: Federico Adrodegari, Nicola Saccani, Christian Kowalkowski \& Jyrki Vilo (2017): PSS business model conceptualization and application, Production Planning \& Control, DOI: 10.1080/09537287.2017.1363924

To link to this article: http://dx.doi.org/10.1080/09537287.2017.136392

(C) 2017 informa UK limited, trading as Taylor \& Francis group 


\section{Introduction}

Capital goods manufacturers pursue service-led growth in order to gain new revenue streams and generate novel competitive advantages, (Neely, 2008; Rapaccini and Visintin, 2015; Peillon, Pellegrin and Burlat, 2015). Servitization, the move towards product-service systems (PSS), or servitization (Baines et al., 2009), affects a company’s business model (Windhal and Lakemond, 2010; Kindström, 2010), e.g. by shifting from selling a product to selling its usage, performance, or functions (Mont, 2002; Lightfoot, Baines and Smart, 2013). However, in a majority of cases capital goods manufacturers still generate a low turnover share through services, mainly from traditional product-related services, such as spare parts, documentation, technical assistance and maintenance (Gebauer, Fleisch and Friedli, 2005; Lay, Schroeter and Biege, 2009; Copani, 2014). Therefore servitization is a not yet mature phenomenon in capital goods sectors, and companies frequently struggle to reconfigure their business model (Evanschitzky, Wangenheim and Woisetschläger, 2011; Kindström and Kowalkowski, 2014).

From a conceptual point of view, moreover, the business model (BM) perspective in describing the move towards PSS has received little attention in the scientific literature, with very few to characterize PSS BMs in a structured way (Adrodegari and Saccani, 2017).

Finally, from a managerial standpoint, a deeper understanding of PSS business models is needed, as well as an increased knowledge on how to implement them in practice (Barquet et al., 2013; Reim, Parida and Örtqvist, 2015).

This paper addresses these gaps, and develops a two-level hierarchical BM framework that can be used to describe PSS business models and guide their development by capital goods companies. The framework is drawn on established BM components from the literature, and it provides an operationalization of each component 
through detailed variables. Moreover, by applying the framework in practice, this paper discusses how it can support industrial companies, and particularly SMEs, in designing their future business model and in consistently planning and deploying the actions needed to implement it.

The paper is organized as follows. Section 2 presents a summary of literatures adopting a BM perspective on servitization. Then, the research process is presented in Section 3 and the new business model framework in section 4. The empirical application of the framework is illustrated in section 5. Finally, section 6 discusses the findings and draws some conclusive remarks, highlighting limitations and future research directions.

\section{Theoretical background}

\subsection{Business model (BM) concept}

In general terms, a BM explains how a business creates and delivers value to customers (Teece, 2010; Baden-Fuller and Morgan, 2010). Although it has been noticed a fragmentation of researchers’ perspectives regarding the nature, structure, and evolution of BM (Morris, Schindehutte, and Allen, 2005; Zott, Amit and Massa, 2011; Coombes and Nicholson, 2013), the literature generally agrees that a BM can bee seen as an abstract tool providing a picture of a company’s competitive situation. In fact, a $\mathrm{BM}$ can be used to describe and analyse the business logic of a company, the value creation mechanisms and how that value is monetized, linking the "inside" with the “outside” of the firm, i.e. suppliers and customers (Wirtz et al., 2016; Baden-Fuller and Mangematin, 2013; Osterwalder and Pigneur, 2010). Therefore, the BM represents a management method that supports strategic decision-making (Osterwalder, Pigneur and Tucci, 2005). 
BM frameworks can be defined as structured ways of describing BMs, encompassing a set of internal and external components that have to be considered when designing, evaluating, and managing BMs (Al-Debei and Avison, 2010; Wirtz et al., 2016). Components usually represent may be further formally described with specific variables. Several BM frameworks appeared in the literature (e.g. Chesborugh, 2007; Johnson, Christensen and Kagermann, 2008; Lindgardt et al., 2009; Demil and Lecoq, 2010; Osterwalder and Pigneur, 2010; Baden-Fuller and Mangematin, 2013). Wirtz et al. (2016) observe that the majority of these works focus on few components. Among the few contributions that give a more comprehensive perspective, one that has gained consensus and diffusion in the managerial and academic communities is the business model Canvas (Osterwalder and Pigneur, 2010). It is based on nine "building blocks” that reflect the most common key components found in the business model literature (Al-Debei and Avison, 2010; Baden-Fuller and Mangematin, 2013; Wirtz et al., 2016). These components are (Osterwalder and Pigneur, 2010):

- Customer segments: groups of people or organizations a company aims to reach and serve;

- Value propositions: products and services that create value for a specific customer segment;

- Distribution channels: company's interface with its customers;

- Customer relationships: types of relationships a company establishes and maintains with specific customer segments;

- Revenue streams: revenue a company generates from each customer segment;

- Key resources: assets required to offer and deliver the aforementioned elements;

- Key activities: activities involved in offering and delivering the aforementioned elements; 
- Key partners: network of suppliers and partners that support the business model execution;

- Cost structure: costs incurred when operating a business model.

The BM Canvas allows distilling the multiplicity of business model components into a simple and parsimonious framework (Aziz et al., 2008). For this reason, it has been adopted by several researchers and practitioners, proving its completeness and adaptability to various industries and topics (e.g Zolnowski et al., 2014; Wiesner et al., 2014; Gibson and Jetter, 2014). Thus, it is not surprising that it has also been applied to PSS settings (e.g. Gelbmann and Hammerl, 2015; Azevedo and Ribeiro, 2013; Barquet et al. 2013; Witell and Löfgren, 2013; Van Ostaeyen et al. 2013).

\subsection{PSS business model frameworks in the literature}

Although the literature pointed out that the required strategic realignment needed in the servitization process should be framed in a structured BM (Kindström, 2010; Kindström and Kowalkowski, 2014; Helms, 2016), PSS BMs have received little attention by research (Boons and Lüdeke-Freund, 2013; Reim et al., 2015).

Adopting the Canvas structure, however, the main elements that characterize a PSS BM can be identified (Adrodegari and Saccani, 2017). Table 1 traces back the elements that describe PSS BMs according to the relevant literature to the nine components of the BM Canvas

\section{[Insert Table 1 near here]}

Table 1 - Relevance of BM components for PSSs

Existing PSS BM frameworks (e.g. Kujala et al., 2011; Barquet et al., 2013; Ferreira et al., 2013; Kindström and Kowalkowski, 2014) generally refer to (some of) 
these key components, but a more fine-grained identification of variables characterizing each component is usually lacking (Adrodegari and Saccani, 2017). However, such a detailed level of formalization would enable a more thorough understanding of the characteristics of servitization, and support PSS BM innovation. In fact, practitioners could assess how their current BM is configured, outline the characteristics of their future one, identify the gaps with respect to all relevant variables, and define actions to move towards a new PSS configuration. The BM framework developed and presented in this paper moves from this gap.

\section{Research process and method}

The research process consisted of two main activities (see Figure 1): 1) developing the PSS BM framework based on the scientific literature, and 2) applying it empirically, which allowed both refining it and exploring its managerial implications.

In order to develop the PSS BM framework, we reviewed the literature that adopts a BM perspective in servitization and PSS. In order to do that, we borrowed an approach often used when relevant research is spread across a number of different literature streams (e.g. Rapaccini and Visintin, 2015). We started our analysis with recently published reviews in the marketing and operations management fields (e.g. Carlborg, Kindström, and Kowalkowski, 2014; Eloranta and Turunen, 2015; Reim et al., 2015; Tukker, 2015; Qu et al., 2016; Brax and Visintin, 2017; Baines et al., 2017; Ziaee Bigdeli et al., 2017) and then backtracked through citations to identify other relevant contributions. At the same time, as a systematization of the current knowledge on the topic could not rely only on the sources adopting a BM approach, we also searched for relevant literature that deals with each of the BM components in Table 1.

[Insert Figure 1 near here]

Figure 1 - Research process 
Building on the analysed body of literature, we developed a first version of the PSS BM framework, where each component was operationalized with variables derived from the literature. The framework was then applied in three companies, in order to test its comprehensiveness and managerial applicability. The studies were carried out within the T-REX project, funded by the European Commission under the $7^{\text {th }}$ Framework Programme. The three companies involved were selected as representative of different sizes and industries, namely machine tool, materials handling and automation. The companies are briefly described in the Table 2.

\section{[Insert Table 2 near here]}

Table 2 - Case companies description

In order to enhance the reliability and validity of the data collection and elaboration activities (Voss, Tsikriktsis and Frohlich, 2002), we designed a specific research protocol. The protocol was based on the PSS BM framework, as it defines the list of aspects to be investigated, and was used as a guideline during the semi-structured interviews and workshops carried out in each company. More precisely, for each company the application started with a half-day workshop that involved the CEO and/or some top managers. The main objectives of the initial workshop were to establish a shared language, illustrate the PSS BM framework and define the unit of analysis (i.e. scope and boundaries of the work). Then, following the guidelines provided in the research protocol, we performed detailed interviews with different roles such as service manager, sales and marketing manager, R\&D manager and information systems manager. Each interview lasted between 1 and 2 hours and involved each manager 
individually. The main evidences were then shared, discussed and validated during a second company workshop.

At this stage, an inter-company workshop was performed, in order to facilitate a cross-case discussion. Experts from other research organizations taking part to the TREX project were also involved, in order to collect external opinions. The initial interviews and the inter-company workshop triggered the revision of the PSS BM framework. In fact, some of the variables initially presented in the framework were considered not relevant for describing the companies’ BMs (e.g. in the Value proposition block we removed the variables related to the product characteristics such as "average life-cycle” or "modularization”) and others have been added or reviewed (e.g. the Key activities component was reviewed in order to better replicate the development and delivery processes of industrial service offerings).

Then, the final version of the framework was used in a company workshop. Expectations and preliminary ideas were discussed with the management in order to define the new PSS BM concept, identifying the product/services in target and the revenue streams. This concept was then translated into detailed BM characteristics, structuring and mapping the new idea with the PSS BM framework. A final workshop was then performed with each company to point out the relevant gaps and the most appropriate actions needed to successfully deploy the new BM.

As an example of how the framework works in a real-world setting, section 5 describes the case of KINE Robot Solutions. This company was selected since it developed the most radical BM innovation among the three cases, moving from a very traditional product-based BM to a result-oriented BM. Moreover, the KINE case allowed testing the model in a very small enterprise, with a product-centric culture and scarce resources. The development of instruments to support the PSS transition in SMEs 
and micro-firms is, in fact, and area were further research is necessary (Gebauer et al., 2012; Kowalkowski et al., 2013).

\section{The PSS business model framework}

In this section we propose a new two-level hierarchical framework that encompasses a broad set of components to be evaluated and characterized when designing the transformation from products to PSSs. In particular, as mentioned in section 2, the proposed framework uses at the first level the components of the BM Canvas, except for the fact the components "Customer Segments” and "Customer Relationships” have been unified within a single component named "Customers”. Such choice guarantees a comprehensive approach to the characterization of PSS BMs, and also the adoption of a shared terminology that facilitates the understanding of the phenomenon among researchers and practitioners alike. This contrasts the terminological fragmentation found both in the BM and PSS literature to date (Wirtz et al., 2016; Tukker, 2015). To fill the need of a greater level of detail in describing PSS BMs, at the second level of the framework each component has been operationalized through specific variables (from two up to five for each component, resulting in a total of 25 variables) according to the process illustrated in section 3. These variables, derived from the literature, correspond to the most relevant aspects that need be characterized in order to describe each BM component in the case of PSS. The framework is described in Table 3, which also includes key managerial questions connected to each variable, to make explicit the practical utility of the framework to managers, thereby facilitating understanding, reflection and decision-making.

[Insert Table 3 near here]

Table 3 - PSS business model framework 


\section{Application - findings from the KINE case}

This section describes the application of the framework to KINE, to discuss how companies face the challenges implied by the move from products to PSSs. The company is a Finish SME with 12 employees and a turnover of around 2 million $€$. KINE designs and delivers robot systems since 2000, providing solutions for production process automation (e.g. packing, palletizing, welding, measuring, material handling, etc.) and traditional product-related services such maintenance and spare parts. The company sells both stand-alone robots and complete systems, designed and assembled based on specific customer needs and delivered as turnkey solutions. Usually, a solution is composed of both standard and non-standard components: in several cases robots, sensors, PLC and electrical components are standard and purchased from long-term suppliers, while the gripper and positioning are customized based on customer's production process. Consequently, interactions with customers are very close during the system design phase, where KINE faces all the typical challenges of One-of-a-kind production Engineer-To-Order companies (Adrodegari et al., 2015). Interactions become looser after system delivery, or may end totally in case the customer decides to carry out after sales services internally or source them from other companies. Also for this reason, the company does not manage systematically customer information, and the majority of the data is collected in MS Excel sheets, with little or no data analysis carried out to develop knowledge (e.g. concerning systems failures). On the contrary, as customer order planning, system production and delivery are very critical activities, the company adopted a specific project management software. A software tool is in place also to handle service requests: however, it is not integrated with the Enterprise Resource Planning system and has been used so far mainly for administrative issues. This picture is coherent with the product-centric approach traditionally adopted by the 
company: the service business was underdeveloped as services are not sold proactively and a structured service business function is missing.

Therefore, in order to gain competitive advantage against larger competitors, the company decided to develop a new PSS business model where the customer will pay based on the output of the production process (pay-per-volume or outcome). In the following table the main characteristics of this new BM are illustrated through the PSS BM framework developed in this paper.

\section{[Insert Table 4 near here]}

Table 4 - KINE’s new PSS business model configuration

The application of the framework allowed the management to develop a clear understanding of the PSS BM concept, and provided a structured description of the new BM. Moreover, it triggered the identification and undertaking of the transformations needed.

Several actions, in fact, were needed to achieve the new BM configuration (see also Table 4). First, the company operational capabilities and human resources had to be aligned with the requirements of the new value proposition: as an example, sales and marketing personnel needed to develop the capabilities to communicate the new offerings to customers and needed to be more integrated with the service function. Moreover, changes were required also outside the company: the establishment of new strategic partnerships (service provider, financing and insurance companies) are needed to sustain the new BM in the financial, logistics, offering, operations and maintenance activities. Respecting the promises is vital for the achievement of customers' objectives in pay-per-outcome, and the service processes were redesigned to be fault-proof. In 
addition, in the new BM, remote diagnostics and product condition analysis are crucial for the company in order to minimize maintenance costs and maximize the value generated by the product use. Therefore, data processing and interpretation capabilities, remote monitoring and condition-based maintenance systems have been developed by the company, also thanks to the EU funded project mentioned in section 3.

Based on the new PSS offering, KINE has recently made a successful tender for a contract with the Finnish Transport Safety Agency, providing marine vessel fuel sulphur content (FSC) remote measurements, as a service. More specifically, the company is paid for every valid FSC measurement that can be connected to a specific marine vessel. To do so, the company has set up multiple measurement stations in the Finnish archipelago near ports with high incoming and outgoing traffic.

Such pilot project helped KINE testing and fine-tuning the BM of the new PSS offering. According to the company's CEO, this is a good example of the value that the PSS BM framework described in this paper can provide to practitioners:

"The knowledge acquired with this project helped us to develop a completely new value proposition that differentiate us from competitors. Moreover the tool (i.e. the framework) let us save time in developing the new offering, as all the issues that need to be managed were known in advance. In fact, the tool allows us to show to our customer that behind the new offering a very structured business model was designed to ensure the credibility of our proposal.” (CEO, KINE).

\section{Conclusion}

\subsection{Research and managerial implications}

Despite the acknowledged importance of the service business, capital goods companies frequently struggle to reconfigure their business models and increase their service 
orientation. The adoption of a business model approach provides a comprehensive understanding to companies aiming to successfully leverage, coordinate and align all the transformations required to servitize, but little research to date has focused on the characterization of PSS business models.

The conceptual output of this paper is a two-level framework, illustrated in Table 3. At the first level, the PSS BM framework is anchored to the general BM literature, and adopts the BM canvas perspective (Osterwalder and Pigneur, 2010) to provide a holistic representation of a PSS BM. This contributes to the harmonization of the terminology adopted by the scientific literature, facilitating a common understanding of the phenomenon for both researchers and practitioners (Tukker, 2015; Wirtz et al., 2016). At the second level, a set of 25 specific variables describe in a detailed way each dimension. Each variable is described and related to the extant literature, and associated to a managerial challenge. The framework constitutes an original contribution of this work, as it connects different aspects that have been often separately addressed by the literature, and contributes to systematize the PSS and servitization literature. It provides a greater formalization of PSS business models, identifying its main components and the relevant variables to characterize each component. Each variable, in turn can be configured among a set of options.

The proposed PSS BM framework can be useful both to researchers and practitioners to characterize and compare different PSS BMs (Tukker, 2004). This is particularly useful when multiple BMs need to be developed and implemented, due to the different types of service offerings delivered and the related revenue models. The coexistence of multiple BMs is a rather under-investigated topic (Benson-Rea et al., 2013; Kowalkowski et al., 2015). The proposed framework can help companies formalizing the existence of these different BMs, highlighting their differences and 
commonalities. In fact, the coexistence of multiple BMs, though generating additional complexity, may also lead to greater efficiency in resource allocation and effectiveness in capabilities exploitation, in particular when moving to PSS. As well, the proposed BM framework can support companies in making the alternative business ideas more concrete. In particular it guides companies in specific reasoning concerning the revenue model, the new cost sources arising, the risks and investments needed to implement each BM. Although the specific and complex issue of selecting among alternative PSS BMs (see for example Battochio et al., 2016) goes beyond the scope of this paper, the proposed framework can help companies in taking into account all the relevant aspects that need to be considered, enabling a comparison between the alternatives. In addition to such an analytical use, as the empirical application shows, the framework can be seen as a practical management tool that provides prescriptive guidelines on how to organize for the provision of PSSs. In fact, the framework provides manufacturers with a holistic approach that can be used to carry out the transition effectively, helping them to take into account the relevant elements that need to be designed to govern the implementation of a PSS BM and guide strategic decisions. In particular, managers can use the proposed framework to understand where their current business model stands, identify where they want to go and thus point out and address the relevant areas to successfully deploy the new PSS configuration. As shown by the case study in section 5, this can be of particular help to SMEs that, due to limited internal resources and limited ability to define a service strategy (Kowalkowski, Witell and Gustafsson, 2013), may need a rigorous yet practical methodological support to undertake such an important change, thus reducing the risk of failure. 


\subsection{Limitation and research opportunities}

As with any research, this study comes with limitations, some of which offer fruitful avenues for research. First, the extension of the empirical research to different sectors would support a greater generalization of the findings. As an example, starting from the theoretically-grounded framework, future research should perform explanatory surveys to test the significance of the variables in different industry sectors.

Second, although the framework provides a detailed and structured description of the PSS BM elements, it adopts a rather static approach. Future research may use this framework to define archetypal BM types that can describe the strategic shift from products to solutions along different service growth trajectories (Kowalkowski et al., 2015), by providing a theoretical configuration of each variable in different BM types.

Finally, since as mentioned before a company may deploy multiple business models simultaneously to serve different markets or customers (Benson-Rea et al., 2013), future research may use the PSS BM framework developed in this paper to analyse the interplay between variables and components when multiple BMs have to be configured.

\section{Acknowledgements}

The work described in this document has been conducted as part of the project T-REX, research project funded by the European Union Seventh Framework Programme (FP7/2007-2013) under grant agreement no 609005 (http://t-rex-fp7).

This paper has also taken inspiration from the activity of the ASAP Service Management Forum (www.asapsmf.org), a community where scholars and practitioners collaborate in developing research projects and share findings in the servitization and service management fields. 


\section{References}

Abdalla, H. (1999). Concurrent engineering for global manufacturing. International Journal of Production Economics. 60-61. pp. 251-260

Adrodegari, F., Bacchetti, A., Pinto, R., Pirola, F., and Zanardini, M. (2015). Engineerto-order (ETO) production planning and control: an empirical framework for machinery-building companies. Production Planning \& Control, 26(11), 910932.

Adrodegari, F., \& Saccani, N. (2017). Business models for the service transformation of industrial firms. The Service Industries Journal, 37(1), 57-83.

Al-Debei, M. M., and Avison, D. (2010). Developing a unified framework of the business model concept. European Journal of Information Systems, 19(3), 359376.

Alghisi, A., and Saccani, N. (2015). Internal and external alignment in the servitization journey-overcoming the challenges. Production Planning \& Control, 26(14-15), 1219-1232.

Ardolino, M., Rapaccini, M., Saccani, N., Gaiardelli, P., Crespi, G., \& Ruggeri, C. (2017). The role of digital technologies for the service transformation of industrial companies. International Journal of Production Research, 1-17.

Araujo, L., and Spring, M. (2006). Services, products, and the institutional structure of production. Industrial Marketing Management, 35(7), 797-805.

Aurich, J. C., Fuchs, C., \& Wagenknecht, C. (2006). Life cycle oriented design of technical Product-Service Systems. Journal of Cleaner Production, 14(17), 1480-1494.

Azevedo, A. (2015). Innovative Costing System Framework in Industrial Productservice System Environment. Procedia Manufacturing, 4, 224-230.

Azarenko, A., Roy, R., Shehab, E., and Tiwari, A. (2009). Technical product-service systems: some implications for the machine tool industry. Journal of Manufacturing Technology Management, 20(5), 700-722.

Azevedo, A. and Ribeiro, H. (2013). New Business Models Elements Oriented to Product-Service Machinery Industry. Advances in Sustainable and Competitive Manufacturing Systems (pp. 1277-1289). Springer International Publishing.

Aziz, S. A. B. D., Fitzsimmons, J., and Douglas, E. (2008). Clarifying the business model construct. Proceedings of AGSE. pp. 795-813.

Badham, R. Couchman, P. and Zanko, M. (2000). Implementing concurrent engineering. Human Factors and Ergonomics in Manufacturing and Service Industries.10 (3), 237-249. 
Baden-Fuller, C., and Morgan,, M. S., (2010). Business models as models. Long Range Planning, 43(2), 156-171.

Baden-Fuller, C., and Mangematin, V., (2013). Business models: A challenging agenda. Strategic Organization, 11(4), 418-427.

Baines, T., and W. Lightfoot, H. (2013). Servitization of the manufacturing firm: Exploring the operations practices and technologies that deliver advanced services. International Journal of Operations and Production Management, 34(1), 2-35.

Baines, T. S., Lightfoot, H. W., Benedettini, O., and Kay, J. M. (2009). The servitization of manufacturing: a review of literature and reflection on future challenges. Journal of Manufacturing Technology Management, 20(5), 547-567.

Baines, T., Lightfoot, H., Smart, P., and Fletcher, S. (2013). Servitization of manufacture: Exploring the deployment and skills of people critical to the delivery of advanced services. Journal of Manufacturing Technology Management, 24(4), 637-646.

Baines, T., Ziaee Bigdeli, A., Bustinza, O. F., Shi, G., Baldwin, J. S., and Ridgway, K. (2017). Servitization: revisiting the state-of-the-art and research priorities. International Journal of Operations \& Production Management, 37(2).

Barquet, A.P.B., de Oliveira, M.G., Amigo, C.R., Cunha V.P. and Rozenfeld H. (2013). Employing the business model concept to support the adoption of productservice systems (PSS). Industrial Marketing Management, 42(5), 693-704.

Batocchio, A., Ghezzi, A., \& Rangone, A. (2016). A method for evaluating business models implementation process. Business Process Management Journal, 22(4), 712-735.

Becker, J., Beverungen, D., Knackstedt, R., Matzner, M., Müller, O., and Pöppelbuß, J. (2013). Bridging the gap between manufacturing and service through IT-based boundary objects. IEEE Transactions on Engineering Management, 60(3), 468482.

Benson-Rea, M., Brodie, R. J., and Sima, H. (2013). The plurality of co-existing business models: Investigating the complexity of value drivers. Industrial Marketing Management, 42(5), 717-729.

Boons, F., and Lüdeke-Freund, F. (2013). Business models for sustainable innovation: state-of-the-art and steps towards a research agenda. Journal of Cleaner Production, 45, 9-19. 
Bonnemeier, S., Burianek, F., and Reichwald, R. (2010). Revenue models for integrated customer solutions: Concept and organizational implementation. Journal of Revenue and Pricing Management, 9(3), 228-238.

Brax, S. A., and Visintin, F. (2017). Meta-model of servitization: The integrative profiling approach. Industrial Marketing Management, 60, 17-32.

Brady, T., Davies, A., and Gann, D. (2005). Creating value by delivering integrated solutions. International Journal of Project Management, 23, 360-365.

Carlborg, P., Kindström, D., and Kowalkowski, C. (2014). The evolution of service innovation research: a critical review and synthesis. Service Industries Journal, 34(5), 373-398.

Cavalieri, S., and Pezzotta, G. (2012). Product-Service Systems Engineering: State of the art and research challenges. Computers in industry, 63(4), 278-288.

Chesbrough, H. (2007), Business model innovation: it’s not just about technology anymore, Strategy and Leadership 35, 12-17.

Coombes, P. H., and Nicholson, J. D. (2013). Business models and their relationship with marketing: A systematic literature review. Industrial Marketing Management, 42(5), 656-664.

Copani, G. (2014). Machine Tool Industry: Beyond Tradition?. In Servitization in Industry (pp. 109- 130). Springer International Publishing

Cova, B., and Salle, R. (2008). Marketing solutions in accordance with the SD logic: Co-creating value with customer network actors. Industrial marketing management, 37(3), 270-277.

Datta, P. P., and Roy, R. (2010). Cost modelling techniques for availability type service support contracts: a literature review and empirical study. CIRP Journal of Manufacturing Science and Technology, 3(2), 142-157.

Davies, A. (2004). Moving base into high-value integrated solutions: a value stream approach. Industrial and Corporate Change, 13(5), 727-756.

Davies, A., Brady, T., and Hobday, M. (2007). Organizing for solutions: Systems seller vs. systems integrator. Industrial marketing management, 36(2), 183-193.

Demil, B., and Lecocq, X. (2010). Business model evolution: in search of dynamic consistency. Long Range Planning, 43(2), 227-246.

De Brentani, U. (1995), New industrial service development - scenarios for success and failure. Journal of Business Research, 32 (2), 93-103 
Dimache, A., and Roche, T. (2013). A decision methodology to support servitisation of manufacturing. International Journal of Operations and Production Management, 33(11), 1435-1457.

Eggert, A., Hogreve, J., Ulaga, W., and Muenkhoff, E. (2014). Revenue and profit implications of industrial service strategies. Journal of Service Research, 17(1), 23-39

Eloranta, V., and Turunen, T. (2015). Seeking competitive advantage with service infusion: a systematic literature review. Journal of Service Management, 26(3), 394-425.

Evanschitzky, H., Wangenheim, F. V., and Woisetschläger, D. M. (2011). Service and solution innovation: overview and research agenda. Industrial Marketing Management, 40(5), 657-660.

Ferreira, F.N.H., Proenca, J.F., Spencer, R., and Cova, B. (2013). The transition from products to solutions: External business model fit and dynamics. Industrial Marketing Management, 42(7), 1093-1101.

Foote, N., Galbraith, J., Hope, Q., and Miller, D. (2001). Making solutions the answer. The McKinsey Quarterly, 3, 84-93.

Gaiardelli, P., Cavalieri, S., and Saccani, N. (2008). Exploring the relationship between after-sales service strategies and design for $\mathrm{X}$ methodologies. International Journal of Product Lifecycle Management, 3(4), 261-278

Gaiardelli, P., Resta, B., Martinez, V., Pinto, R., \& Albores, P. (2014). A classification model for product-service offerings. Journal of cleaner production, 66, 507-519.

Galbraith, J. (2002). Designing organizations: An executive guide to strategy, structure and process. San Francisco: Jossey-Bass.

Gao J., Yao Y., Zhu V.C.Y., Sun L., and Lin L. (2011). Service oriented manufacturing: A new product pattern and manufacturing paradigm. Journal of Intelligent Manufacturing, 22(3), 435-446.

Gebauer, H. (2011). Exploring the contribution of management innovation to the evolution of dynamic capabilities. Industrial Marketing Management, 40(8), 1238-1250.

Gebauer, H., Fleisch, E., and Friedli, T. (2005). Overcoming the service paradox in manufacturing companies. European Management Journal, 23(1), 14-26

Gebauer, H. and Kowalkowski, C. (2012), Customer-focused and service-focused orientation in organizational structures, Journal of Business and Industrial Marketing, 27(7), 527-537. 
Gebauer, H., Paiola, M., and Edvardsson, B. (2012). A capability perspective on service business development in small and medium-sized suppliers. Scandinavian Journal of Management, 28(4), 321-339.

Gebauer, H., Paiola, M., and Saccani, N. (2013). Characterizing service networks for moving from products to solutions. Industrial Marketing Management, 42(1), 31-46.

Gelbmann, U., and Hammerl, B. (2015). Integrative re-use systems as innovative business models for devising sustainable product-service-systems. Journal of Cleaner Production, 97, 50-60.

Gibson, E. and Jetter, A. (2014). Towards a dynamic process for business model innovation: A review of the state-of-the-art. In Management of Engineering and Technology. Portland International Conference. 1230-1238

Grönroos, C. (2011). A service perspective on business relationships: The value creation, interaction and marketing interface. Industrial marketing management, 40(2), 240-247.

Helander, A., and Möller, K. (2008). How to become solution provider: System supplier's strategic tools. Journal of Business-to-Business Marketing, 15(3), 247289.

Helms, T. (2016). Asset transformation and the challenges to servitize a utility business model. Energy Policy, 91, 98-112.

Isaksson, O., Larsson, T. C., and Rönnbäck, Ö. (2009). Development of product-service systems: Challenges and opportunities for the manufacturing firm. Journal of Engineering Design, 20(4), 21.

Johnson, M. W., Christensen, C. M. and Kagermann, H. (2008). Reinventing your business model. Harvard Business Review, 86(12), 50-59.

Kindström, D. (2010). Towards a service-based business model - Key aspects for future competitive advantage. European Management Journal, 28(6), 479-490.

Kindström, D., and Kowalkowski, C. (2009). Development of industrial service offerings: a process framework. Journal of service Management, 20(2), 156-172.

Kindström, D. and Kowalkowski, C. (2014). Service innovation in product-centric firms: A multidimensional business model perspective. Journal of Business and Industrial Marketing, 29(2), 96-111.

Kindström, D., Kowalkowski, C., and Alejandro, T. B. (2015). Adding services to product-based portfolios: An exploration of the implications for the sales function. Journal of Service Management, 26(3), 372-393. 
Kowalkowski, C. (2011). Dynamics of value propositions: insights from servicedominant logic. European Journal of Marketing, 45(1/2), 277-294.

Kowalkowski, C., Witell, L., and Gustafsson, A. (2013). Any way goes: Identifying value constellations for service infusion in SMEs. Industrial Marketing Management, 42(1), 18-30.

Kowalkowski, C., Windahl, C., Kindström, D., and Gebauer, H. (2015). What service transition? Rethinking established assumptions about manufacturers' service-led growth strategies. Industrial Marketing Management, 45, 59-69

Kujala S., Artto K., Aaltonen P., and Turkulainen V. (2010). Business models in project-based firms - Towards a typology of solution-specific business models. International Journal of Project Management, 28(2), 96-106.

Kujala S., Kujala J., Turkulainen V., Artto K., Aaltonen P., and Wikstrom K. (2011). Factors influencing the choice of solution-specific business models. International Journal of Project Management, 29(8), 960-970.

Lay, G., Schroeter, M., and Biege, S. (2009). Service-based business concepts: A typology for business-to-business markets. European Management Journal, 27(6), 442-455.

Lightfoot, H., Baines, T., and Smart, P. (2013). The servitization of manufacturing: A systematic literature review of interdependent trends. International Journal of Operations and Production Management, 33(11;12), 1408-1434.

Lindgart, Z., Reeves, M., Stalk, G., and Deimler, M. S. (2009). Business Model Innovation. When the game gets though, change the game. The Boston Consulting Group.

Liu C.H., Chen M.-C., Tu Y.-H., and Wang C.-C. (2014). Constructing a sustainable service business model: An S-D logic-based integrated product service system. International Journal of Physical Distribution and Logistics Management, 44(1), 80-97.

Lusch, R. F., \& Vargo, S. L. (2006). Service-dominant logic: reactions, reflections and refinements. Marketing theory, 6(3), 281-288.

Martinez, V., Bastl, M., Kingston, J., and Evans, E. (2010). Challenges in transforming manufacturing organisations into product-service providers. Journal of Manufacturing Technology Management, 21(4), 449-469. 
Mathieu, V. (2001). Service strategies within the manufacturing sector: benefits, costs and partnership. International Journal of Service Industry Management, 12(5), 451-475.

Meier H., Roy R., and Seliger G. (2010). Industrial Product-Service systems-IPS2. CIRP Annals - Manufacturing Technology, 59(2), 607-627.

Meier H., Volker O., and Funke B. (2011). Industrial Product-Service Systems (IPS2) : Paradigm shift by mutually determined products and services. International Journal of Advanced Manufacturing Technology, 52(41982), 1175-1191.

Meier, H., Lagemann, H., Morlock, F., and Rathmann, C. (2013). Key performance indicators for assessing the planning and delivery of industrial services. Procedia CIRP, 11, 99-104.

Miller, D., Hope, Q., Eisengstat R., Foote and N.and Galbraith (2002). The problem of solutions: Balancing clients and capabilities. Business Horizons, 45(2), 3-12

Mont, O., (2002). Clarifying the concept of product-service system. Journal of Cleaner Production, 10(3), 237-245.

Mont O., Dalhammar C., and Jacobsson N. (2006). A new business model for baby prams based on leasing and product remanufacturing. Journal of Cleaner Production, 14(17), 1509-1518.

Morris, M., Schindehutte, M., and Allen, J. (2005). The entrepreneur's business model: toward a unified perspective. Journal of Business Research, 58(6), 726-735.

Neely, A. (2008). Exploring the financial consequences of the servitization of manufacturing. Operations Management Research, 1(2), 103-118.

Neff, A. A., Hamel, F., Herz, T. P., Uebernickel, F., Brenner, W., and vom Brocke, J. (2014). Developing a maturity model for service systems in heavy equipment manufacturing enterprises. Information and management, 51(7), 895-911.

Nenonen, S., and Storbacka, K. (2010). Business model design: conceptualizing networked value co-creation. International Journal of Quality and Service Sciences, 2(1), 43-59.

Ng, I. C., Maull, R., and Yip, N. (2009). Outcome-based contracts as a driver for systems thinking and service-dominant logic in service science: Evidence from the defence industry. European Management Journal, 27(6), 377-387.

Ng, I. C., Ding, D. X., and Yip, N. (2013). Outcome-based contracts as new business model: The role of partnership and value-driven relational assets. Industrial Marketing Management, 42(5), 730-743 
Nordin, F., and Kowalkowski, C. (2010). Solutions offerings: a critical review and reconceptualisation. Journal of Service Management, 21(4), 441-459.

Nordin, F., Kindström, D., Kowalkowski, C. and Rehme, J. (2011), The risks of providing services: differential risk effects of the service-development strategies of customisation, bundling, and range, Journal of Service Management, 22(3), 390-408.

Oliva, R., and Kallenberg, R. (2003). Managing the transition from products to services. International journal of service industry management, 14(2), 160-172.

Osterwalder, A., Pigneur, Y., and Tucci, C. L. (2005). Clarifying business models: Origins, present, and future of the concept. Communications of the association for Information Systems, 16(1), 1.

Osterwalder, A., and Pigneur, Y. (2010). Business model generation: a handbook for visionaries, game changers, and challengers.

Paiola, M., Saccani, N., Perona, M., and Gebauer, H. (2013). Moving from products to solutions: Strategic approaches for developing capabilities. European Management Journal, 31(4), 390-409.

Payne, A. and Holt, S. (2001), Diagnosing customer value: integrating the value process and relationship marketing. British Journal of Management, 12 (2). 159-82

Payne, A.F., Storbacka, K. and Frow, P. (2008). Managing the co-creation of value. Journal of the Academy of Marketing Science, 36(1), 83-96

Pawar, K. S., Beltagui, A., and Riedel, J. C. (2009). The PSO triangle: designing product, service and organisation to create value. International Journal of Operations and Production Management, 29(5), 468-493.

Peillon, S., Pellegrin, C., \& Burlat, P. (2015). Exploring the servitization path: a conceptual framework and a case study from the capital goods industry. Production Planning \& Control, 26(14-15), 1264-1277.

Porter, M. E., and Heppelmann, J. E. (2014). How smart, connected products are transforming competition. Harvard Business Review, 92(11), 11-64.

Prahalad, C. K., \& Ramaswamy, V. (2004). Co-creation experiences: The next practice in value creation. Journal of interactive marketing, 18(3), 5-14.

Qu, M., Yu, S., Chen, D., Chu, J., and Tian, B. (2016). State-of-the-art of design, evaluation, and operation methodologies in product service systems. Computers in industry, 77, 1-14. 
Rapaccini, M. (2015). Pricing strategies of service offerings in manufacturing companies: a literature review and empirical investigation. Production Planning \& Control, 26(14-15), 1247-1263.

Rapaccini, M., Saccani, N., Pezzotta, G., Burger, T., and Ganz, W. (2013). Service development in product-service systems: a maturity model. The Service Industries Journal, 33(3-4), 300-319.

Rapaccini, M., and Visintin, F. (2015). Devising hybrid solutions: an exploratory framework. Production Planning \& Control, 26(8), 654-672.

Reinartz, W., and Ulaga, W. (2008). How to sell services more profitably. Harvard business review, 86(5), 90.

Reim, W., Parida, V., and Örtqvist, D. (2015). Product-Service Systems (PSS) business models and tactics-a systematic literature review. Journal of Cleaner Production, 97, 61-75.

Rexfelt, O., and Hiort af Ornäs, V. (2009). Consumer acceptance of product-service systems: designing for relative advantages and uncertainty reductions. Journal of Manufacturing Technology Management, 20(5), 674-699.

Richter A., Sadek T., and Steven M. (2010). Flexibility in industrial product-service systems and use-oriented business models. CIRP Journal of Manufacturing Science and Technology, 3(2), 128-134.

Saccani, N., Visintin, F., and Rapaccini, M. (2014). Investigating the linkages between service types and supplier relationships in servitized environments. International Journal of Production Economics, 149, 226-238

Schuh, G., Boos, W., Kozielski, S., 2009. Lifecycle cost-orientated service models for tool and die companies. In: Proceedings of the 19th CIRP Design Conference competitive Design. Cranfield University Press, pp. 249-254.

Settanni, E., Newnes, L. B., Thenent, N. E., Parry, G., and Goh, Y. M. (2014). A through-life costing methodology for use in product-service-systems. International Journal of Production Economics, 153, 161-177.

Sheth, J. N., and Uslay, C. (2007). Implications of the revised definition of marketing: from exchange to value creation. Journal of Public Policy and Marketing, 26(2), 302-307.

Smith, L., Ng, I., and Maull, R. (2012). The three value proposition cycles of equipment-based service. Production Planning \& Control, 23(7), 553-570. 
Spring, M., and Araujo, L. (2009). Service, services and products: rethinking operations strategy. International Journal of Operations and Production Management, 29(5), 444-467.

Storbacka K. (2011). A solution business model: capabilities and management practices for integrated solutions. Industrial Marketing Management, 40(5), 699-711.

Storbacka, K., Windahl, C., Nenonen, S., and Salonen, A. (2013). Solution business models: Transformation along four continua. Industrial Marketing Management, 42(5), 705-716.

Sundin, E., Bras, B., 2005. Making functional sales environmentally and economically beneficial through product remanufacturing. Journal of Cleaner Production 13 (9), 913-925.

Teece, D. J. (2010). Business models, business strategy and innovation. Long range planning, 43(2), 172-194.

Tukker, A. (2004). Eight types of product-service system: eight ways to sustainability? Experiences from SusProNet. Business strategy and the environment, 13(4), 246-260.

Tukker, A. (2015). Product services for a resource-efficient and circular economy-a review. Journal of Cleaner Production, 97, 76-91.

Tukker, A., and Tischner, U. (2006). Product-services as a research field: past, present and future. Reflections from a decade of research. Journal of cleaner production, 14(17), 1552-1556.

Tuli, K. R., Kohli, A. K., and Bharadwaj, S. G. (2007). Rethinking customer solutions: From product bundles to relational processes. Journal of Marketing, 71(3), 1-17.

Ulaga, W., and Reinartz, W. J. (2011). Hybrid offerings: how manufacturing firms combine goods and services successfully. Journal of Marketing, 75(6), 5-23.

Ulaga, W., and Loveland, J. M. (2014). Transitioning from product to service-led growth in manufacturing firms: Emergent challenges in selecting and managing the industrial sales force. Industrial Marketing Management, 43(1), 113-125.

Van Ostaeyen J., Van Horenbeek A., Pintelon L., and Duflou J.R. (2013). A refined typology of product-service systems based on functional hierarchy modeling. Journal of Cleaner Production, 51, 261-276.

Vargo, S. L., and Lusch, R. F. (2004). Evolving to a new dominant logic for marketing. Journal of marketing, 68(1), 1-17. 
Vargo, S. L., and Lusch, R. F. (2008). Service-dominant logic: continuing the evolution. Journal of the Academy of marketing Science, 36(1), 1-10.

Voss, C., Tsikriktsis, N. and Frohlich, M. (2002), Case research in operations management, International Journal of Operations and Production Management, 22(2), 195-219.

Ward, Y. and Graves, A. (2007), Through-life management: the provision of total customer solutions in the aerospace industry, International Journal of Services Technology and Management, 8(6), 455-77.

Wiesner, S., Padrock, P. and Thoben, K.D. (2014) Extended Product Business Model in Four Manufacturing Case Studies. Procedia CIRP, 16, 110-115

Windahl, C., and Lakemond, N. (2010). Integrated solutions from a service-centered perspective: applicability and limitations in the capital goods industry. Industrial Marketing Management, 39(8), 1278-1290.

Wirtz, B. W., Pistoia, A., Ullrich, S., \& Göttel, V. (2016). Business models: Origin, development and future research perspectives. Long Range Planning, 49(1), 3654.

Wise, R. and Baumgartner, P. (1999), Go Downstream: The New Profit Imperative in Manufacturing. Harvard Business Review, 77 (5), 133-141

Witell, L., and Löfgren, M. (2013). From service for free to service for fee: business model innovation in manufacturing firms. Journal of Service Management, 24(5), 520-533.

Zheng, M., Ming, X., Li, M., and He, L. (2015). A framework for Industrial ProductService Systems risk management. Proceedings of the Institution of Mechanical Engineers, Part O: Journal of Risk and Reliability, 229(6), 501-516

Ziaee Bigdeli, A., Baines, T., Bustinza, O. F., and Guang Shi, V. (2017). Organisational Change towards Servitization: A Theoretical Framework. Competitiveness Review: An International Business Journal, 27(1).

Zolnowski, A., C. Weiß and T. Böhmann (2014). Representing Service Business Models with the Service Business Model Canvas - The Case of a Mobile Payment Service in the Retail Industry. 47th Hawaii International Conference on System Sciences (HICSS-47). Hilton Waikoloa, Big Island.

Zott, C., Amit, R., and Massa, L. (2011). The business model: recent developments and future research. Journal of management, 37(4), 1019-1042. 


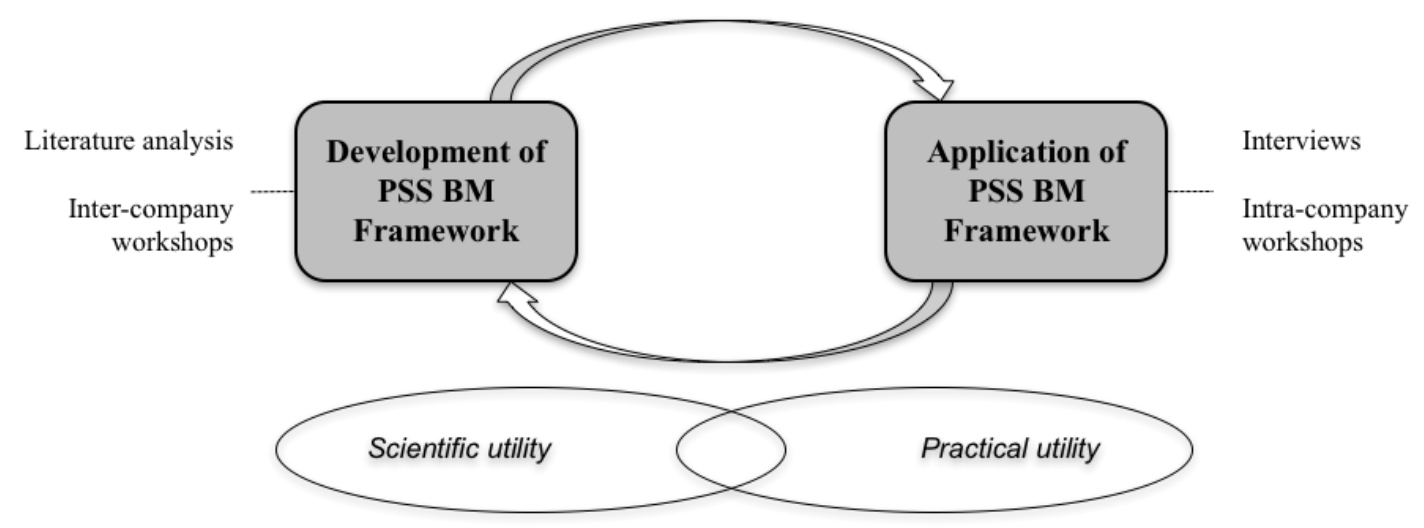

Figure 1 - Research process 


\begin{tabular}{|c|c|}
\hline $\begin{array}{c}\text { BM } \\
\text { Component }\end{array}$ & Relevance for PSS \\
\hline $\begin{array}{c}\text { Value } \\
\text { proposition }\end{array}$ & $\begin{array}{l}\text { Defining PSS value proposition is more than understanding what services to offer } \\
\text { and how to develop a coherent portfolio (Kindström and Kowalkowski, 2014). In } \\
\text { PSS, a switch from value-in-exchange to value-in-use occurs (Vargo and Lusch, } \\
\text { 2004; Ng, Maull, and Yip, 2009; Grönroos, 2011): the value for the customer can be } \\
\text { generated in various way, introducing different configurations of value proposition } \\
\text { (Tukker, 2004; Smith, Ng and Maull, 2012; Brax and Visintin, 2017). As an } \\
\text { example, customers may perceive as a direct source of value the ownership of the } \\
\text { product, or vice versa value can be generated by using the product without having } \\
\text { the ownership of it (Kujala et al., 2010; Barquet et al., 2013; Reim et al., 2015). In } \\
\text { PSS BMs, these different approaches generate new different configurations of } \\
\text { company/customer responsibilities (Ferreira et al., 2013; Gelbmann and Hammerl, } \\
\text { 2015). }\end{array}$ \\
\hline $\begin{array}{l}\text { Customer } \\
\text { segments }\end{array}$ & $\begin{array}{l}\text { Addressing the right customer segment with the appropriate value proposition is a } \\
\text { critical factor for the success of the PSSs (Kindström, 2010): in fact, not all types of } \\
\text { value propositions fit all customers (Rexfelt and Hiort af Ornäs, 2009). In PSSs, an } \\
\text { effective value generation is achieved when a fit between the company's and } \\
\text { customers' BMs occurs (Nenonen and Storbacka, 2010; Ferreira et al., 2013). Thus, } \\
\text { it is critical to define the target customer group, in order to understand how } \\
\text { customers' perception, depending on their culture or mindset, can influence a } \\
\text { specific value proposition (Reim et al., 2015; Storbacka et al., 2013). }\end{array}$ \\
\hline $\begin{array}{l}\text { Customer } \\
\text { relationships }\end{array}$ & $\begin{array}{l}\text { In PSSs, customer relationships (e.g. customer closeness and customer focus) are } \\
\text { critical success factors (Reim et al., 2015; Kindström, 2010; Davies et al., 2007; } \\
\text { Tukker, 2004; Gebauer et al., 2005; Galbraith, 2002). In fact, it is important to } \\
\text { define which kind of interaction has to be established with the customer in order to } \\
\text { enable the value delivery and maintain it throughout the product lifecycle (Meier, } \\
\text { Roy and Seliger, 2010; Barquet et al., 2013; Liu et al., 2014). Moreover, increased } \\
\text { customer interaction (in time and intensity) is a distinguishing factor of servitized } \\
\text { BMs (Azarenko, Roy, Shehab, and Tiwari, 2009). This encompasses also the } \\
\text { definition of the extent to which the company and the customer have to share } \\
\text { information (Reim et al., 2015; Windhal and Lakemond, 2010). }\end{array}$ \\
\hline $\begin{array}{c}\text { Key } \\
\text { resources }\end{array}$ & $\begin{array}{l}\text { Companies need to acquire/develop a whole new set of distinctive resources: } \\
\text { competencies to deal with customers should be developed, people trained and } \\
\text { sometimes additional personnel recruited (Ulaga and Reinartz, 2011; Baines et al., } \\
\text { 2013; Kindström and Kowalkowski, 2014). Manufacturers need financial resources } \\
\text { to sustain the transition to different revenue models (Lay et al., 2009; Reim et al., } \\
\text { 2015) and new technologies to better manage, analyse and share the wider amount } \\
\text { of data that have to be generated and controlled to sustain PSS business models } \\
\text { (Meier et al., 2011; Barquet et al., 2013; Liu et al., 2014). }\end{array}$ \\
\hline Key activities & $\begin{array}{l}\text { It identifies the processes that are critical for the success of service development and } \\
\text { delivery (Lay et al., 2009; Kindström and Kowalkowski, 2014). In PSSs companies } \\
\text { may outsource activities that previously were performed internally and may acquire } \\
\text { resources from outside their borders (Storbacka, 2011; Dimache and Roche, 2013). } \\
\text { Moreover, service innovation may require industrial firms to change their internal } \\
\text { organisation (Kindström and Kowalkowski, 2009) in order to deploy new service- } \\
\text { related activities (Rapaccini et al., 2013; Cavalieri and Pezzotta, 2012). }\end{array}$ \\
\hline Channels & $\begin{array}{l}\text { As it is very important to understand how the new value proposition is delivered to } \\
\text { customers, in PSS BMs companies need to rethink the way through which they } \\
\text { create awareness on the new service offering and communicate the new added value } \\
\text { (Reim et al., 2015). In PSSs environments this can lead to reconfigure sales and } \\
\text { after-sales channels by internalizing/externalizing specific resources as well as to } \\
\text { acquire or develop new kinds of competencies (Storbacka, 2011; Kindström and } \\
\text { Kowalkowski, 2014). }\end{array}$ \\
\hline
\end{tabular}




\begin{tabular}{|c|l|}
\hline $\begin{array}{c}\text { BM } \\
\text { Component }\end{array}$ & \multicolumn{1}{c|}{ Relevance for PSS } \\
\hline Key partners & $\begin{array}{l}\text { It defines the composition and structure of the network that is needed to sustain the } \\
\text { PSS BM. Defining the types of actors through which share responsibilities and value } \\
\text { generated with the new offering becomes crucial (Ferreira et al., 2013; Liu et al., } \\
\text { 2014; Reim et al., 2015). Moreover, in PSS BMs, it becomes critical moving from } \\
\text { short to long term or from price based to strategic based relationships (Storbacka, } \\
\text { 2011; Barquet et al., 2013). }\end{array}$ \\
\hline Cost structure \\
$\begin{array}{l}\text { As cash-flow structure can radically change in PSSs (Mont et al., 2006; Eggert et } \\
\text { al., 2014), it defines how financial and accounting practices need adaptations (Meier } \\
\text { et al., 2010; Barquet, 2013; Reim et al., 2015). Traditional assessment procedures of } \\
\text { investment planning or cost management are no longer sufficient, since the } \\
\text { timescale of financial flows may change considerably (Neely, 2008; Richter, Sadek } \\
\text { and Steven, 2010; Storbacka, 2011; Settanni et al., 2014). Moreover, risk } \\
\text { management activities become critical (Zheng et al., 2015). }\end{array}$ \\
\hline $\begin{array}{l}\text { Revenue } \\
\text { model } \\
\text { based on the value for the customer generated (Kujala et al., 2010; Barquet et al., } \\
\text { 2013; Kindström and Kowalkowski, 2014). With the shift from ownership to } \\
\text { access, the revenue model evolves from one-off transactions and to continuous } \\
\text { payment over time to outcome- or output-based (Tukker, 2004; Kindström and } \\
\text { Kowalkowski, 2014). However, rather mixed payment mechanisms are quite } \\
\text { common in the case of PSSs (Van Ostaeyen et al., 2013; Rapaccini, 2015). }\end{array}$ \\
\hline
\end{tabular}

Table 1 - Relevance of BM components for PSSs

\begin{tabular}{|c|c|c|c|}
\hline Company & Description & $\begin{array}{l}\text { Strategic objective of the } \\
\text { move to PSS }\end{array}$ & Research contribution \\
\hline $\mathbf{A}$ & $\begin{array}{l}\text { - Spanish company } \\
\text { - } 160 \text { employees } \\
\text { - Focuses on the sales and } \\
\text { rental of forklift trucks. }\end{array}$ & $\begin{array}{l}\text { - Further exploitation of the } \\
\text { rental fleet (lifecycle } \\
\text { extension) } \\
\text { - Maintain strong link with } \\
\text { current BM, current } \\
\text { customers and their needs }\end{array}$ & $\begin{array}{l}\text { Test the model in a (already) } \\
\text { servitized environment. }\end{array}$ \\
\hline $\mathbf{B}$ & $\begin{array}{l}\text { Italian company } \\
\text { - } 350 \text { employees } \\
\text { - Manufacturer of high-end } \\
\text { numerical controls, and } \\
\text { high speed milling } \\
\text { machines. }\end{array}$ & $\begin{array}{l}\text { - Use of monitoring } \\
\text { technologies to enable } \\
\text { advanced services } \\
\text { - Service business growth } \\
\text { (revenue, profits) }\end{array}$ & $\begin{array}{l}\text { Test the model in a traditional } \\
\text { product-centric company that } \\
\text { aims to enlarge its service } \\
\text { portfolio (incremental } \\
\text { innovation). }\end{array}$ \\
\hline KINE & $\begin{array}{l}\text { Finnish company } \\
\text { - } 12 \text { employees } \\
\text { Operates in the field of } \\
\text { robot system integration. }\end{array}$ & $\begin{array}{l}\text { - Develop new revenue } \\
\text { mechanisms to compete } \\
\text { against larger competitors } \\
\text { - Create a new service- } \\
\text { based culture (company } \\
\text { and customers) }\end{array}$ & $\begin{array}{l}\text { Test the model in a product- } \\
\text { centric company that aims to } \\
\text { move towards a completely } \\
\text { new PSS business model } \\
\text { (radical innovation). }\end{array}$ \\
\hline
\end{tabular}

Table 2 - Case companies description 


\begin{tabular}{|c|c|c|c|}
\hline Component & Variable & Main change in PSS BMs & Managerial questions (challenges) \\
\hline \multirow[t]{4}{*}{$\begin{array}{c}\text { Value } \\
\text { proposition }\end{array}$} & $\begin{array}{l}\text { Value for the } \\
\text { customer }\end{array}$ & $\begin{array}{l}\text { Defining value for customer (Windahl and Lakemond, 2010) is the starting point for } \\
\text { PSSs definition (Payne and Holt, 2001; Mont, 2002; Vargo and Lusch, 2004; Pawar, } \\
\text { Beltagui and Riedel, 2009). In PSS value for the customer can be generated by the } \\
\text { reduction of initial investment, minimization and/or guarantee of operational cost, or } \\
\text { functional guarantee and minimization of risk for the customer over the lifecycle (e.g. } \\
\text { Morris et al., 2005; Isaksson, Larsson, and Rönnbäck, 2009; Baruqet et al., 2013). }\end{array}$ & $\begin{array}{l}\text { 1. What are the main sources of value for the } \\
\text { customer in the new BM? } \\
\text { 2. Which value for the customer has to be } \\
\text { delivered with the new BM? }\end{array}$ \\
\hline & $\begin{array}{l}\text { Creation of } \\
\text { value }\end{array}$ & $\begin{array}{l}\text { In product-centric models value is created in the firm and then exchanged with the } \\
\text { customer, as value is an embedded attribute of the product (Kowalkowski, 2011). } \\
\text { Instead, in PSSs value is interactional (Pawar et al., 2009) and co-created (Prahalad and } \\
\text { Ramaswamy 2004; Sheth and Uslay, 2007), as it is generated through the access or the } \\
\text { usage of a product (Lay et al., 2009; Storbacka et al. 2013). Thus, a switch from value- } \\
\text { in-exchange to value-in-use occurs (Vargo and Lusch, 2004; Ng et al., 2009; Grönroos, } \\
\text { 2011): value cannot be objectively determined or delivered by the provider in isolation } \\
\text { (Vargo and Lusch, 2004; Smith et al., 2012). }\end{array}$ & $\begin{array}{l}\text { 1. Which current or new solutions does the } \\
\text { company want to deliver with the new business } \\
\text { model? } \\
\text { 2. How will the value creation process occur } \\
\text { (lifecycle phase, activities and processes } \\
\text { involved, expected role of customer and } \\
\text { supplier)? }\end{array}$ \\
\hline & $\begin{array}{l}\text { Product } \\
\text { ownership }\end{array}$ & $\begin{array}{l}\text { The ownership of the physical product, that describes who has the product right after the } \\
\text { contract expires (Lay et al., 2009), is not obvious in PSS business models: it can either } \\
\text { be passed to the customer or remain with the manufacturer. The "non-ownership" } \\
\text { concept is the basis for several types of PSS BM (Tukker, 2004). Moving towards PSSs, } \\
\text { the reliance on the product as the core component decreases and the customer's need can } \\
\text { be formulated in more abstract terms. }\end{array}$ & $\begin{array}{l}\text { 1. Does the customer want to: i.) Own the } \\
\text { product? ii.) Gain access to the product (e.g. } \\
\text { lease, rent)? iii.) Benefit from the results of the } \\
\text { product usage? } \\
\text { 2.Would the company be inclined to remain the } \\
\text { owner of the product during its whole life-cycle? }\end{array}$ \\
\hline & $\begin{array}{l}\text { Service } \\
\text { offering }\end{array}$ & $\begin{array}{l}\text { The extension of service components in the total offering is a key trigger for providing } \\
\text { PSSs (Davies, 2004). Different classifications describe the evolution of the offerings in } \\
\text { PSS BMs: e.g. Mathieu, 2001; Ulaga and Reinartz, 2011; Gaiardelli et al. 2014; } \\
\text { Kindström and Kowalkowski, 2014. Generally, as offerings become more servitized, } \\
\text { companies include advanced services and services supporting the customer (Baines et } \\
\text { al., 2017; Paiola et al., 2013). }\end{array}$ & $\begin{array}{l}\text { 1. Which current or new services does the } \\
\text { company want to deliver with the new business } \\
\text { model? } \\
\text { 2. Moreover, identify the width of service } \\
\text { offering, in terms of incidence of base, } \\
\text { intermediate and advanced ones and relevance of } \\
\text { different lifecycle phases. }\end{array}$ \\
\hline
\end{tabular}




\begin{tabular}{|c|c|c|c|}
\hline Component & Variable & Main change in PSS BMs & Managerial questions (challenges) \\
\hline \multirow[t]{4}{*}{ Customers } & $\begin{array}{l}\text { Customer } \\
\text { interactions }\end{array}$ & $\begin{array}{l}\text { In PSSs, a tight relationship and improved interaction between the company and its } \\
\text { customers are important success factors (e.g., Cova and Salle, 2008; Davies et al., 2007; } \\
\text { Galbraith, 2002), enabling the mutual creation of value. In fact, the success of the value } \\
\text { co-creation process relies heavily on customers' efforts and involvement (Sheth and } \\
\text { Uslay, 2007). Increased customer interaction is therefore a distinguishing factor for PSS } \\
\text { BMs (Kindström, 2010; Spring and Araujo, 2009; Vargo and Lusch, 2008, Storbacka et } \\
\text { al., 2013). Customer interaction and participation in design, production, sales and } \\
\text { delivery are essential characteristics of PSSs (Kindström and Kowalkowski, 2009). }\end{array}$ & $\begin{array}{l}\text { 1. Are closer relationships with customers } \\
\text { needed in the new PSS BM? } \\
\text { 2. How customer interactions should be } \\
\text { designed? }\end{array}$ \\
\hline & $\begin{array}{l}\text { Customers' } \\
\text { information } \\
\text { sharing }\end{array}$ & $\begin{array}{l}\text { Information sharing between the company and the customer is a prerequisite (or a } \\
\text { consequence) to establishing close customer relationships (Reim et al., 2015; Kindström, } \\
\text { 2010; Mont, 2002). Moreover, collecting/exchanging information and realizing how to } \\
\text { use data allows the manufacturer to become knowledgeable about customer operations } \\
\text { (Ulaga and Reinartz, 2011). In fact, customers' provision of information and guidance } \\
\text { about their operations and policies helps the supplier provide better services (Kindström } \\
\text { and Kowalkowski, 2014). }\end{array}$ & $\begin{array}{l}\text { 1.Is information sharing to be enhanced in the } \\
\text { new BM? If so on which aspects? } \\
\text { 2. Which operational and strategic benefit could } \\
\text { be achieved? } \\
\text { 3. Does the company need to put in place new } \\
\text { actions for that (information tools, increase } \\
\text { "trust" with partners, change sales/service people } \\
\text { mind-sets, ...)? }\end{array}$ \\
\hline & $\begin{array}{l}\text { Customer and } \\
\text { market insight }\end{array}$ & $\begin{array}{l}\text { In PSS, as the creation of value has to be understood through the eyes of the customers } \\
\text { (Brady et al., 2005; Davies, 2004), it becomes critical to achieve an excellent } \\
\text { understanding of customers, their operations and business (Kindström, 2010; Reim et al., } \\
\text { 2015). Consequently, the company should acquire and analyse data and information both } \\
\text { about customer problems and their operations in order to create and deliver a clear value } \\
\text { proposition that matches real customer preferences and needs. Moreover, when it } \\
\text { understands its customers, a company can influence their needs (Payne et al., 2008). }\end{array}$ & $\begin{array}{l}\text { 1. Does the company need to collect information } \\
\text { about the customers for the new BM? } \\
\text { 2. Which kind of information? } \\
\text { 3. How can it be transformed into valuable } \\
\text { knowledge? }\end{array}$ \\
\hline & $\begin{array}{l}\text { Target } \\
\text { customers and } \\
\text { segments }\end{array}$ & $\begin{array}{l}\text { A company has to develop segment-specific strategies, including business goals (Foote } \\
\text { et al., 2001; Miller et al., 2002). Therefore, different criteria should be implemented to } \\
\text { segment and analyse (potential and actual) customer needs. In particular, in PSS BMs } \\
\text { companies need to develop customer-specific value propositions, which are unique and } \\
\text { linked to critical business concerns of an individual customer (Storbacka, 2011). For this } \\
\text { reason, the company has to define focus markets, segments and customers for its } \\
\text { business (Storbacka, 2011), In PSSs, customers can be segmented using multiple and } \\
\text { advanced criteria that consider different types of user behaviour, since the new offering } \\
\text { involves changes in ownership, responsibility, availability and cost. }\end{array}$ & $\begin{array}{l}\text { 1. Which current or new customer(s) segments } \\
\text { does the company want to address with the new } \\
\text { business model? } \\
2 \text {. Which customer segmentation criteria will } \\
\text { help in the definition and sale of the new value } \\
\text { proposition? } \\
\text { 3. Is the information needed to deploy the new } \\
\text { customer segmentation available? If not, how can } \\
\text { it be gathered? }\end{array}$ \\
\hline
\end{tabular}




\begin{tabular}{|c|c|c|c|}
\hline Component & Variable & Main change in PSS BMs & Managerial questions (challenges) \\
\hline \multirow[t]{4}{*}{$\begin{array}{c}\text { Key } \\
\text { Resources }\end{array}$} & $\begin{array}{l}\text { ICT and } \\
\text { monitoring } \\
\text { technologies }\end{array}$ & $\begin{array}{l}\text { ICT and digital technologies enable PSS BMs (Becker et al., 2013; Ardolino et al., } \\
\text { 2017). ICT systems allow to share information and knowledge extracted from data } \\
\text { collected among different functions (Storbacka, 2011) and also towards customer and } \\
\text { partners. Thus traditional software systems (e.g. ERP, CRM, PLM, PDM, SRM) should } \\
\text { be fully integrated, and applications that support supply chain management and } \\
\text { collaboration activities should be implemented (Neff et al., 2014). PSS BMs require the } \\
\text { enhanced usage of remote technology (Neff et al., 2014), such as the Internet of Things: } \\
\text { embedded ICT systems become very sophisticated and open up possibilities for remote } \\
\text { services such as supervision, maintenance, process improvements, and upgrades. }\end{array}$ & $\begin{array}{l}\text { 1. Which information systems are needed in the } \\
\text { new BM to collect and manage data and } \\
\text { information related with customers, installed } \\
\text { products and product-enabled processes? } \\
\text { 2. Which (new) digital technologies should be } \\
\text { developed to implement the PSS BM? }\end{array}$ \\
\hline & $\begin{array}{l}\text { Installed base } \\
\text { information }\end{array}$ & $\begin{array}{l}\text { Product installed base represents a unique asset for most manufacturing firms (Wise and } \\
\text { Baumgartner, 1999; Ulaga and Reinartz, 2011). Particularly in PSS BMs, managing the } \\
\text { installed base is salient, as it is a source of knowledge and creates critical insights about } \\
\text { the products' operation, enabling new service offerings and revenue models (Storbacka, } \\
\text { 2011). The level of control that a company exerts on data and information generated by } \\
\text { the customer during the usage of the product is crucial: collecting and updating historic } \\
\text { data after repair and maintenance events, the use of condition monitoring for preventive } \\
\text { maintenance and optimising the customer processes (Neff et al., 2014) depend on the } \\
\text { company's control on installed base information. }\end{array}$ & $\begin{array}{l}\text { 1.Does the company have any control over its } \\
\text { installed base? } \\
\text { 2. Which information is critical to gather } \\
\text { valuable customer or product knowledge from } \\
\text { the field? } \\
\text { 3. How can information from the installed base } \\
\text { (customer, location, maintenance history, usage } \\
\text { history) be gathered? }\end{array}$ \\
\hline & Human & $\begin{array}{l}\text { In PSS BMs, a shift of mindset and corporate culture is required to increase the service } \\
\text { orientation of the organization at all levels (Gebauer et al., 2005; Barquet et al., 2013). } \\
\text { Thus, companies must make considerable investments in human resources to develop } \\
\text { new competencies, re-configure existing ones (Kindström and Kowalkowski, 2014; } \\
\text { Ulaga and Loveland, 2014; Storbacka, 2011; Ulaga and Reinartz, 2011; Gebauer, 2011; } \\
\text { Kindström, 2010; Helander and Möller, 2008), or to hire new personnel (Ulaga and } \\
\text { Reinartz, 2011; Gebauer, Paiola and Edvardsson, 2012; Kindström and Kowalkowski, } \\
\text { 2014). }\end{array}$ & $\begin{array}{l}\text { 1. Which kind of new and distinctive skills have } \\
\text { to be developed or strengthened in the new BM? } \\
\text { 2. How can these be achieved (training, new } \\
\text { personnel, new procedures, new information } \\
\text { systems, ...)? }\end{array}$ \\
\hline & Financial & $\begin{array}{l}\text { In PSS BMs the need for capital is high, since the company may remain the owner of the } \\
\text { product and the payback period of a product-service system is usually longer than of a } \\
\text { physical product sales (Tukker, 2004; Barquet et al., 2013). Companies must have } \\
\text { adequate financial resources or receive support from financing partners to bridge this } \\
\text { period (Mont, 2002). Moreover, offering a wide range of services in this business model } \\
\text { and taking over operational risks also implies greater financial risk for the company } \\
\text { (Kindström and Kowalkowski, 2014; Alghisi and Saccani, 2015). }\end{array}$ & $\begin{array}{l}\text { 1. What is the amount of financial resources } \\
\text { needed to deploy the new PSS BM? } \\
\text { 2. What partners should be involved to cover the } \\
\text { financial risks (e.g. banks, insurance companies, } \\
\text {...)? }\end{array}$ \\
\hline
\end{tabular}




\begin{tabular}{|c|c|c|c|}
\hline Component & Variable & Main change in PSS BMs & Managerial questions (challenges) \\
\hline \multirow[t]{3}{*}{$\begin{array}{c}\text { Key } \\
\text { activities }\end{array}$} & $\begin{array}{l}\text { Product } \\
\text { development } \\
\text { and design }\end{array}$ & $\begin{array}{l}\text { In PSS BMs, to meet product and service design requirements, special emphasis is } \\
\text { placed on aligning physical product characteristics with service (Reim et al., 2015). } \\
\text { Moreover, the company is usually responsible for all lifecycle costs in PSS BMs. This } \\
\text { provides a powerful incentive to design a product that minimizes the overall lifecycle } \\
\text { cost (lifecycle extension and minimization of operating cost), easy to maintain } \\
\text { (Azarenko et al., 2009) and whose elements can be re-used at the end of the products life } \\
\text { (Tukker 2004; Datta and Roy, 2010) and. Several product properties such as the ability } \\
\text { to be maintained, upgraded, and reused easily, can be identified and improved in the } \\
\text { design phase in order to facilitate the provision of product-related services (Badham et } \\
\text { al. 2000; Abdalla, 1999) and increase the value creation of the new business model } \\
\text { (Sundin and Bras, 2005; Gaiardelli, Cavalieri and Saccani, 2008). }\end{array}$ & $\begin{array}{l}\text { 1. Which (product) features should be enhanced } \\
\text { in the new BM (e.g. reliability, serviceability, } \\
\text { durability, end-of-life, modularity)? } \\
\text { 2. Which redesign actions should be carried out? } \\
\text { 3. Is an increased data collection and } \\
\text { transmission capability (e.g. sensors, IoT) } \\
\text { required? }\end{array}$ \\
\hline & $\begin{array}{l}\text { Services } \\
\text { design and } \\
\text { engineering }\end{array}$ & $\begin{array}{l}\text { Refers to the ideation/innovation of service components that can improve PSS offerings } \\
\text { to better fit customer needs and make value creation possible (Tuli, Kohli and } \\
\text { Bharadwaj, 2007; Pawar et al., 2009; Kindström and Kowalkowski, 2009). New service } \\
\text { development and service engineering activities may help product centric-firms to } \\
\text { successfully extend their service offering and its integration level with the tangible } \\
\text { component (Rapaccini et al., 2013). Specific methods and roles should be involved } \\
\text { (Cavalieri and Pezzotta, 2012) }\end{array}$ & $\begin{array}{l}\text { 1. How can an explicit strategy, procedures, roles } \\
\text { and tools for new service development be } \\
\text { introduced in the new BM? }\end{array}$ \\
\hline & $\begin{array}{l}\text { Products and } \\
\text { services } \\
\text { configuration } \\
\text { support }\end{array}$ & $\begin{array}{l}\text { Refers to the definition of a new offering with specific product and services } \\
\text { configuration to create value for the individual customer (Tuli et al., 2007; Storbacka, } \\
\text { 2011). PSS offerings are complex: focusing on value-driven communication becomes } \\
\text { central (Reim et al., 2015) as the company needs to show to potential customers the } \\
\text { value of the new offering. To this end, specific strategies and methods (e.g. Total Cost of } \\
\text { Ownership, Service Level Agreement) are essential to help customers appreciate the } \\
\text { distinctiveness and benefits of PSS (de Brentani, 2001). Thus, front-line employees } \\
\text { should have sufficient knowledge in order to convincingly sell and transmit the new } \\
\text { value to the customers (Kindström and Kowalkowski, 2009; Kindström, Kowalkowski } \\
\text { and Alejandro, 2015). Often, a new reward system is needed to promote service sales } \\
\text { and change the behaviour of a product-centric sales force (Reinartz and Ulaga, 2008; } \\
\text { Kndström, 2010; Kindström and Kowalkowski, 2014). }\end{array}$ & $\begin{array}{l}\text { 1. Which tools can support the configuration of } \\
\text { the individual PSS offering for a customer } \\
\text { 2. Which methods can be used to best show the } \\
\text { value for the customer of the new offering (e.g. } \\
\text { Total cost of ownership or lifecycle costing } \\
\text { evaluation, development of Service Level } \\
\text { Agreements, ...)? }\end{array}$ \\
\hline
\end{tabular}




\begin{tabular}{|c|c|c|c|}
\hline Component & Variable & Main change in PSS BMs & Managerial questions (challenges) \\
\hline \multirow[t]{2}{*}{$\begin{array}{c}\text { Key } \\
\text { activities }\end{array}$} & $\begin{array}{l}\text { Products and } \\
\text { services } \\
\text { delivery }\end{array}$ & $\begin{array}{l}\text { In PSS BMS, both service delivery planning and execution activities need to be closely } \\
\text { managed (Meier et al. 2013) in order to guarantee that integrated systems can be made } \\
\text { available in an efficient manner (Storbacka, 2011; Tulli et al. 2007). To enable quick } \\
\text { ramp-up of delivery operations and secure long-term embeddedness with customers } \\
\text { (Storbacka, 2011), the delivery process should be carefully monitored. It is therefore } \\
\text { important to verify and report both to customers and internally to the company that the } \\
\text { planned value has been created, and to document successful deliveries (Kindström and } \\
\text { Kowalkowski, 2009). Service delivery becomes more than providing spare parts, } \\
\text { operating information and routine maintenance: remote diagnostics and product } \\
\text { condition analysis are crucial to minimize lifecycle costs and maximize the value } \\
\text { generated by the product (Meier et al., 2010; Rapaccini and Visintin, 2015). }\end{array}$ & $\begin{array}{l}\text { 1.Which indicators have to be defined and } \\
\text { monitored to track the effectiveness of the PSS } \\
\text { delivery? How will they be communicated to the } \\
\text { customers? } \\
\text { 2. Which set of Key Performance Indicators } \\
\text { (KPIs) better describe the efficiency and } \\
\text { effectiveness of PSS delivery? How can they be } \\
\text { timely monitored and shared within the } \\
\text { organisation and the partner network? }\end{array}$ \\
\hline & $\begin{array}{l}\text { Intra-firm } \\
\text { collaboration } \\
\text { and } \\
\text { integration }\end{array}$ & $\begin{array}{l}\text { PSS BMs need to establish formal processes and mechanisms to carry out cross- } \\
\text { functional activities (Kindström et al., 2015) and achieve cross-functional integration } \\
\text { (Storbacka et al., 2013; Nordin and Kowalkowski, 2010). In particular, PSS BMs } \\
\text { especially call for collaboration between the service organization and R\&D and/or } \\
\text { product development (Kowalkowski, 2011; Kindström and Kowalkowski, 2014). } \\
\text { Moreover, as the service offered becomes more sophisticated the need arises for } \\
\text { effective coordination of sales and after-sales processes in every step of the product } \\
\text { lifecycle, providing the customer with a unique and direct touch-point (Kindström et al., } \\
\text { 2015). Thus PSS BMs require a collaborative management and the measures used to } \\
\text { control the business have to acknowledge this cross-functional nature (Storbacka, 2011). }\end{array}$ & $\begin{array}{l}\text { 1. Is the collaboration among service and } \\
\text { technical functions, marketing/sales personnel, } \\
\text { more important in the new BM? On which } \\
\text { aspects in particular? } \\
\text { 2. Are practices to enhance internal collaboration } \\
\text { already in place or being designed? }\end{array}$ \\
\hline $\begin{array}{c}\text { Key } \\
\text { Partners }\end{array}$ & Network & $\begin{array}{l}\text { Providing PSSs increase complexity in the company's operations (Reim et al., 2015; } \\
\text { Barquet et al., 2013) and thus firm must develop new networks infrastructures (Gao et } \\
\text { al., 2011) to share capabilities and jointly create value (Aurajo and Spring, 2006; Lusch } \\
\text { and Vargo, 2006). The network should be designed concurrently with the new value } \\
\text { proposition (Aurich et al., 2006; Mont et al., 2006; Ward and Graves, 2007), specifying } \\
\text { each partner's role and value throughout the product lifecycle (Storbacka, 2011). Thus, } \\
\text { the establishment of such a network requires the identification of actors and of the core } \\
\text { competencies they can provide (Mont, 2002; Barquet et al., 2013). Finding partners that } \\
\text { can add value to the new offering (Kindström, 2010) is critical, and supplier selection } \\
\text { should be based on strategic consideration rather than price based criteria (Mont, 2002; } \\
\text { Aurajo and Spring, 2006; Lusch and Vargo, 2006; Kindström, 2010). }\end{array}$ & $\begin{array}{l}\text { 1. Identify the main types of (relevant) suppliers } \\
\text { involved in the new BM and, for each type: } \\
\text { specify if you need new suppliers with respect to } \\
\text { the current BM; specify if you need to build } \\
\text { long-term partnership with each type of suppliers } \\
\text { or not; add any other category if useful and } \\
\text { report the entire list. } \\
\text { 2. Would be possible to configure and establish a } \\
\text { network of suppliers and partners to acquire } \\
\text { resources, capabilities and even reduce risks of } \\
\text { the new business model? }\end{array}$ \\
\hline
\end{tabular}




\begin{tabular}{|c|c|c|c|}
\hline Component & Variable & Main change in PSS BMs & Managerial questions (challenges) \\
\hline $\begin{array}{c}\text { Key } \\
\text { Partners }\end{array}$ & $\begin{array}{l}\text { Supplier } \\
\text { relationship }\end{array}$ & $\begin{array}{l}\text { In PSS BMs, strong relationships with critical suppliers are needed (Gebauer et al., } \\
\text { 2013): actors within the new network become increasingly dependent on each other's } \\
\text { processes, which requires harmonization across and within organizational boundaries } \\
\text { (Brady et al., 2005; Oliva and Kallenberg, 2003; Storbacka, 2011). In particular, the } \\
\text { management of upstream relationships with the network in charge of providing services } \\
\text { is critical in a servitized environment (Martinez et al., 2010, Gebauer et al., 2013). After } \\
\text { choosing partners, much effort is needed to develop ways to coordinate the relationships } \\
\text { and share the right information efficiently in the network (Schuh et al., 2009). In fact, } \\
\text { given the effort needed for setting-up a long-term relationship, this should rely on } \\
\text { cooperation and on a significant and bidirectional information exchange (Saccani et al., } \\
\text { 2014). Thus, the interface and the communication with partners may require specific } \\
\text { attention, in order to secure transparency and long-term quality (Storbacka, 2011). }\end{array}$ & $\begin{array}{l}\text { 1. Are long terms relationship and information } \\
\text { sharing with partners crucial in the new BM? If } \\
\text { so with which partners? } \\
\text { 2. Is that different from the current BM? } \\
\text { 3. Does the company need to put in place new } \\
\text { actions for that (information tools, increase } \\
\text { "trust" with partners, ...)? }\end{array}$ \\
\hline Channels & $\begin{array}{l}\text { Sales channel } \\
\text { configuration }\end{array}$ & $\begin{array}{l}\text { In PSS BMs, the sales channel should be able to create customer awareness and enable } \\
\text { the offering evaluation. Thus, sales and marketing personnel need to develop } \\
\text { trustworthiness, reliability knowledge/experience on the new PSS offering and becomes } \\
\text { a resource to be used by customers for the creation of additional value (Kindström et al., } \\
\text { 2015). Because of the increasing comprehensiveness of the company's value proposition, } \\
\text { the sales-force should modify their sales strategy (Kindström et al., 2015). In fact, the } \\
\text { salesperson needs to devote more attention and effort to communicating value to the } \\
\text { customer: a direct interface with the end customer is needed in order to define selling } \\
\text { parameters primarily driven by customer perceived value creation instead of internal } \\
\text { cost. }\end{array}$ & $\begin{array}{l}\text { 1. Does the company need internal (direct) or } \\
\text { external sales channels for the new BM? } \\
\text { 2. Will they be the same as for the current BM? } \\
\text { 3. Which actions/improvements/modification } \\
\text { have to be done? }\end{array}$ \\
\hline Channels & $\begin{array}{l}\text { After sales } \\
\text { channel and } \\
\text { field service } \\
\text { network }\end{array}$ & $\begin{array}{l}\text { A field service network is a prerequisite for successful delivery PSSs and it includes both } \\
\text { the internal service organization and external service partners (Kindström and } \\
\text { Kowalkowski, 2014). Since actual delivery of services becomes a key activity that can } \\
\text { directly affect customer satisfaction and retention, a company often need to develop new } \\
\text { resource base geared to service provision (Kindström, 2010). In fact, field technicians } \\
\text { interact frequently with customers, and customers tend to trust them more (especially if } \\
\text { they are located full time on customer sites), which makes them a key resource for sales } \\
\text { (Ulaga and Reinartz, 2011). For this reason, in PSS BMs the after-sales channel should } \\
\text { be highly integrated with the sales one, providing the customer with a unique and direct } \\
\text { touch point that hold the entire customer related knowledge. Thus, it should be useful to } \\
\text { establish specific, customer-focused units that can be coupled with a key account } \\
\text { management approach (Gebauer and Kowalkowski, 2012; Kindström et al., 2015). }\end{array}$ & $\begin{array}{l}\text { 1. Does the company need internal (direct) or } \\
\text { external after-sales channels for the new BM? } \\
\text { 2. Will they be the same as for the current BM? } \\
\text { 3. Which actions/improvements/modification } \\
\text { have to be done? } \\
\text { 4. Which degree of interaction and integration } \\
\text { between sales and after-sales channels has to be } \\
\text { designed? On which aspects? }\end{array}$ \\
\hline
\end{tabular}




\begin{tabular}{|c|c|c|c|}
\hline Component & Variable & Main change in PSS BMs & Managerial questions (challenges) \\
\hline Cost & $\begin{array}{l}\text { Cost structure } \\
\text { composition } \\
\text { and } \\
\text { management }\end{array}$ & $\begin{array}{l}\text { When a function is sold rather than ownership, cost structures should be arranged to } \\
\text { support a new demand of cash-flow (Barquet, 2013; Azevedo, 2015). Moreover, new } \\
\text { non-recurring, overheads and hidden costs became relevant (Datta and Roy, 2010). They } \\
\text { include issues such as cost of relationship management, communication costs, costs of } \\
\text { reverse logistics and flexibility of response and costs of cultural changes or change } \\
\text { management (Meier et al. 2010). Moreover, since the timescale of the financial flows } \\
\text { change considerably, accounting practices need adaptations (Barquet, 2013; Azevedo, } \\
\text { 2015). In fact, traditional assessment procedures of investment planning or of cost } \\
\text { management are no longer sufficient in this new setting (Richeter et al. 2010; Datta and } \\
\text { Roy, 2010). Moreover, cost control should supports sales by standard costing data on } \\
\text { solutions and individual solution component: as pricing PSSs is much more demanding } \\
\text { than pricing individual products, firms usually have to provide updated standard costing } \\
\text { data. }\end{array}$ & $\begin{array}{l}\text { 1. Which elements concerning internal } \\
\text { organization, cost structure, and competitive } \\
\text { factors could be introduced or raised above the } \\
\text { industry's standard? } \\
\text { 2. Does the company need new resources (tools, } \\
\text { methods, competences, ...) for cost control } \\
\text { activities in the new BM? }\end{array}$ \\
\hline Cost & Risk & $\begin{array}{l}\text { In PSSs, when defining a value proposition, a company should entail the risk component } \\
\text { and define in advance how it is going to be shared among the actors involved in the new } \\
\text { business model (Tukker, 2004; Azarenko et al., 2009; Meier et al., 2010). In fact, as } \\
\text { moving into PSS BMs implies accepting more responsibility for the customer's } \\
\text { operations, there is a significant risk issue to consider (Foote et al., 2001; Spring and } \\
\text { Araujo, 2009; Nordin et al., 2011). Therefore, risk assessment and mitigation capabilities } \\
\text { are required (Kindström and Kowalkowski, 2014; Zheng et al. 2015). Sharing } \\
\text { uncertainty and risk with all the actors involved in the new offering is critical: companies } \\
\text { and customers should jointly identify, plan, assess, handle and monitor these } \\
\text { uncertainties and risks (Meier et al. 2010). }\end{array}$ & $\begin{array}{l}\text { 1. Which type of risks does the company incur } \\
\text { with in the new BM (e.g. financial, operational, } \\
\text { adverse customer's behaviour, ...)? } \\
\text { 2. Is that new compared to the current BM? } \\
\text { 3. How can the company mitigate those risks } \\
\text { (e.g. insurance, data collection and analysis to } \\
\text { predict events, shared risk mechanism, risk } \\
\text { premium, ...)? }\end{array}$ \\
\hline Revenue & $\begin{array}{l}\text { Revenue } \\
\text { stream }\end{array}$ & $\begin{array}{l}\text { Moving to PSS BMs, instead of one-off payments, companies can structure their sales to } \\
\text { customers in different ways (Van Osteayen et al., 2013). Payment may be based, for } \\
\text { example, on the availability of the product and/or service, on how often the product } \\
\text { and/or service is used, on the end result of the use of products and/ or services (Barquet } \\
\text { et al. 2013). The type of revenue mechanism employed is strictly linked to the chosen } \\
\text { value proposition and depends on a number of variables such as customer maturity and } \\
\text { the degree of a supplier company's internal focus on the customer and its business } \\
\text { (Kindström, 2010). }\end{array}$ & $\begin{array}{l}\text { 1. How would the company gain revenues in the } \\
\text { new BM? } \\
\text { 2. Identify the main company's revenue sources } \\
\text { in the new BM product sales, corrective } \\
\text { maintenance sales, maintenance contracts sales, } \\
\text { product rental, spare parts sales,... . }\end{array}$ \\
\hline
\end{tabular}




\begin{tabular}{|c|c|c|c|}
\hline Component & Variable & Main change in PSS BMs & Managerial questions (challenges) \\
\hline & $\begin{array}{l}\text { Contractual } \\
\text { agreements }\end{array}$ & $\begin{array}{l}\text { Moving from cost-plus pricing to value-based pricing requires the development of a new } \\
\text { pricing discipline (Rapaccini, 2015): risks and economic potential are hard to predict but } \\
\text { new pricing models are essential to ensure profitability in PSS BMs (Oliva and } \\
\text { Kallenberg, 2003; Tukker and Tischner, 2006; Neely; 2008). In particular in PSS BMs, } \\
\text { when ownership is not transferred to the customer, decision rights must be allocated } \\
\text { carefully (Richter et al., 2010) and it is crucial to define reliable outcome expectations } \\
\text { that meet contractually agreed performance (Bonnemeier et al., 2010). Thus, there is a } \\
\text { need for the company to manage new offering through the composition of specific and } \\
\text { structured business deals/agreements that describe how rights and liabilities are } \\
\text { distributed among the involved parties (Azarenko et al., 2009; Meier et al., 2010; Reim } \\
\text { et al., 2015). Thus, complex contracts may be used to outline roles, procedures and } \\
\text { penalties for non-compliance and determine outcomes/performances to be delivered by } \\
\text { the PSS (Ng et al. 2013). }\end{array}$ & $\begin{array}{l}\text { 1.What elements should be agreed upon with the } \\
\text { customer and formalized in a written contract? } \\
\text { 2.Is expertise for specialized external partners } \\
\text { needed to write down contractual agreements? }\end{array}$ \\
\hline
\end{tabular}

Table 3 - PSS business model framework 


\begin{tabular}{|c|c|c|}
\hline Component & Variable & PSS business model \\
\hline \multirow[t]{4}{*}{$\begin{array}{l}\text { Value } \\
\text { proposition }\end{array}$} & $\begin{array}{l}\text { Value for the } \\
\text { customer }\end{array}$ & $\begin{array}{l}\text { It is generated by the reduction of initial investment and functional guarantee. Moreover, KINE becomes responsible for services } \\
\text { during the whole life-cycle and this leads to the minimization of operational costs and risks for the customer to achieve an expected } \\
\text { outcome. }\end{array}$ \\
\hline & Creation of value & Value is created through the system's usage. Thus, value creation is interactional and the customer becomes a co-creator of value. \\
\hline & Product ownership & KINE remains the owner of the system, while the customer pays a periodic fee for its usage. \\
\hline & Service offering & $\begin{array}{l}\text { New advanced services to be added to the offering, such as: remote monitoring and diagnostics, condition based maintenance, and } \\
\text { also the taking over of the system's operations at the customer's by KINE, if requested by the customer. }\end{array}$ \\
\hline \multirow[t]{4}{*}{ Customers } & $\begin{array}{l}\text { Customer } \\
\text { interactions }\end{array}$ & $\begin{array}{l}\text { Maintaining customer relationships becomes a priority. } \\
\text { Mindset needs to become more customer-oriented especially in the service function. }\end{array}$ \\
\hline & $\begin{array}{l}\text { Customers' } \\
\text { information sharing }\end{array}$ & $\begin{array}{l}\text { Key information to be shared with the customer concerns, e.g.: produced units, faults and maintenance activities, running hours, } \\
\text { energy and material consumption. }\end{array}$ \\
\hline & $\begin{array}{l}\text { Customer and } \\
\text { market insight }\end{array}$ & $\begin{array}{l}\text { KINE is updated about customers preferences, problems and needs. In particular KINE acquires information on the production } \\
\text { process, schedules, and system maintenance history. }\end{array}$ \\
\hline & $\begin{array}{l}\text { Target customers } \\
\text { and segments }\end{array}$ & $\begin{array}{l}\text { The PSS BM is addressing in particular customers operating in the logistics field (packing, palletizing, order picking, transport etc.). } \\
\text { Other segments can be addressed with pilot cases. }\end{array}$ \\
\hline \multirow[t]{4}{*}{$\begin{array}{l}\text { Key } \\
\text { Resources }\end{array}$} & $\begin{array}{l}\text { ICT and monitoring } \\
\text { technologies }\end{array}$ & $\begin{array}{l}\text { New sensors and remote signals/diagnostics control are implemented to enable remote monitoring. Health management systems are } \\
\text { used to monitor performance and usage conditions of the system. An ad-hoc information system is implemented to ease the } \\
\text { information management process inside KINE. }\end{array}$ \\
\hline & $\begin{array}{l}\text { Installed base } \\
\text { information }\end{array}$ & $\begin{array}{l}\text { KINE collects and manage service-related data (e.g. maintenance activities), product and process related data (e.g. product usage, } \\
\text { performance, ...) and data related to customers' use of the product. Such data allow monitoring the system (functionality and } \\
\text { performance) and plan proactive interventions. }\end{array}$ \\
\hline & Human & $\begin{array}{l}\text { In order to set-up a new service orientation of human resources and corporate culture, new competences have been identified, for both } \\
\text { service and sales personnel. Examples are: data processing and interpretation capability, execution risk assessment and mitigation } \\
\text { capability, design-to-service capability, hybrid offering sales capability and hybrid offering deployment capability. Diagnostic } \\
\text { capabilities are also needed for service technicians }\end{array}$ \\
\hline & Financial & $\begin{array}{l}\text { High financial capabilities are a prerequisite to cover the investments, in particular related to system building (material investment in } \\
\text { form of loans or finance). Also new technologies and tools, personnel (people, training, knowledge upkeep), and marketing require } \\
\text { adequate financial resources. }\end{array}$ \\
\hline \multirow[t]{2}{*}{$\begin{array}{c}\text { Key } \\
\text { activities }\end{array}$} & $\begin{array}{l}\text { Product development } \\
\text { and design }\end{array}$ & $\begin{array}{l}\text { The system should minimize the overall lifecycle cost, with the possibility to re-use elements. Thus, system modularization and } \\
\text { "Design for X" techniques will be implemented. }\end{array}$ \\
\hline & $\begin{array}{l}\text { Services design and } \\
\text { engineering }\end{array}$ & $\begin{array}{l}\text { Service engineering activities allow to effectively and efficiently design a customized contract to address specific customer needs, and } \\
\text { the related services. Moreover, new procedures and roles are needed to formalize the development of new service offering. }\end{array}$ \\
\hline
\end{tabular}




\begin{tabular}{|c|c|c|}
\hline Component & Variable & PSS business model \\
\hline & $\begin{array}{l}\text { Offering } \\
\text { configurations }\end{array}$ & $\begin{array}{l}\text { Focusing on value-driven communication is crucial when the offering is complex. Sales and account managers have to work } \\
\text { proactively with customers already before they send out a request for quotation. To support the sales force making the advantages for } \\
\text { customers tangible, KINE developed specific sales tools based on the Total Cost of Ownership method. }\end{array}$ \\
\hline & $\begin{array}{l}\text { Products and } \\
\text { services delivery }\end{array}$ & $\begin{array}{l}\text { With remote diagnostics and product condition analysis the effectiveness and efficiency of (preventive) maintenance is improved, } \\
\text { minimizing maintenance costs and maximizing the value generated by the product use. }\end{array}$ \\
\hline & $\begin{array}{l}\text { Intra-firm } \\
\text { collaboration and } \\
\text { integration }\end{array}$ & $\begin{array}{l}\text { The collaboration among the company’s personnel is formalized with specific procedures. Moreover, inter-functional periodic } \\
\text { meetings are in place: all participants can submit in advance issues to be discussed. Follow-up minutes are shared within the company. } \\
\text { Minutes would record actions, deadlines and responsibilities agreed, and any divergent opinion if required by a participant. }\end{array}$ \\
\hline \multirow[t]{2}{*}{ Key Partners } & Partners network & $\begin{array}{l}\text { Main partners in the new BM are: robot manufacturers, key subcontractors, sensor technology subcontractors, ICT systems integrators } \\
\text { and finance partners. When selecting partners, their availability to adapt to the new revenue model should be considered. }\end{array}$ \\
\hline & $\begin{array}{l}\text { Suppliers } \\
\text { relationship }\end{array}$ & $\begin{array}{l}\text { The objective is to strengthen the relationships and focus on key suppliers. } \\
\text { Bug fixing and field-testing are important tasks of integrators, and reporting to suppliers will be increased. Information is shared } \\
\text { openly between the partners and customer information secured with the signature of non-disclosure agreements. Web-based } \\
\text { applications to ease the exchange of information will be developed. }\end{array}$ \\
\hline \multirow[t]{2}{*}{ Channels } & $\begin{array}{l}\text { Sales channel } \\
\text { configuration }\end{array}$ & $\begin{array}{l}\text { Main sales channel is the same as in current BM (direct contacts). However, the salespersons need to devote more effort to explaining } \\
\text { the value to the customer. Moreover, the direct interface with the end customer will facilitate the definition of selling parameters } \\
\text { primarily driven by customer perceived value instead than internal cost. }\end{array}$ \\
\hline & $\begin{array}{l}\text { After sales channel / } \\
\text { field service network }\end{array}$ & $\begin{array}{l}\text { After-sales service personnel are mainly internal and highly integrated in every step of the product lifecycle with the sales-force. } \\
\text { Field technicians will be specialized on specific customers/solutions. }\end{array}$ \\
\hline \multirow[t]{2}{*}{ Cost } & Risk & $\begin{array}{l}\text { The main risks are related to: customer conditions changes, service personnel changes, costs calculation estimations, customer interest } \\
\text { on carrying on the contract (= showing benefits), predicting failures. These risks can be mitigated with contract length, and contract } \\
\text { conditions (extra-fees for changing agree-settings). }\end{array}$ \\
\hline & $\begin{array}{l}\text { Cost structure } \\
\text { composition and } \\
\text { management }\end{array}$ & $\begin{array}{l}\text { In a new 5-year contract, the cost structure can be estimated as follows: (1) System: initial costs of material, } 25 \% \text {; direct labour, } 10 \% \text {; } \\
\text { subcontract, } 5 \% \text {. (2) Service: remote services, system user, maintenance, spare parts, modification, upgrades, ...: 50\%. Indirect cost } \\
\text { (sales and marketing, R\&D, other fixed cost, ...): } 15 \% \text {. }\end{array}$ \\
\hline \multirow[b]{2}{*}{ Revenue } & Revenue stream & $\begin{array}{l}\text { Revenue streams consist of prepayment, payment at customer acceptance and periodic fee based on "pay-per-x" invoicing with a } \\
\text { minimum contractually-set fee (to ensure that the system will not be left unused without any sort of invoicing). }\end{array}$ \\
\hline & $\begin{array}{l}\text { Contractual } \\
\text { agreements }\end{array}$ & $\begin{array}{l}\text { Invoicing and the invoice bases are agreed in contracts. Main parameters are as follow: } \\
\text { - Monthly payments based on system usage, with e.g. system usage = Production time (or the time spent producing items). } \\
\text { - Metrics for the service: MTTR and availability level. }\end{array}$ \\
\hline
\end{tabular}

Table 4 - KINE's new PSS business model configuration 